\title{
Effects of Suckling on the Udder Health of Foster Cows
}

\author{
Katharina Köllmann ${ }^{1}$, Yanchao Zhang ${ }^{1}{ }^{\circledR}$, Nicole Wente ${ }^{1}{ }^{\mathbb{D}}$, Anneke Lücken ${ }^{1}$, Stefanie Leimbach ${ }^{1}$ \\ and Volker Krömker ${ }^{2, *}$ (1)
}

1 Department of Microbiology, Faculty of Mechanical and Bioprocess Engineering, University of Applied Sciences and Arts, 30453 Hannover, Germany; Katharina.Marie.Koellmann@tiho-hannover.de (K.K.); yanchao.zhang@hs-hannover.de (Y.Z.); nicole.wente@hs-hannover.de (N.W.); anneke.luecken@hs-hannover.de (A.L.); stefanie.leimbach@hs-hannover.de (S.L.)

2 Department of Veterinary and Animal Sciences, University of Copenhagen, 1870 Frederiksberg, Denmark

* Correspondence: Volker.Kroemker@sund.ku.dk

Citation: Köllmann, K.; Zhang, Y.; Wente, N.; Lücken, A.; Leimbach, S.; Krömker, V. Effects of Suckling on the Udder Health of Foster Cows.

Ruminants 2021, 1, 100-117. https:// doi.org/10.3390/ruminants1020008

Academic Editor: Maria Luisa Dettori

Received: 4 July 2021

Accepted: 26 September 2021

Published: 9 October 2021

Publisher's Note: MDPI stays neutral with regard to jurisdictional claims in published maps and institutional affiliations.

Copyright: (c) 2021 by the authors. Licensee MDPI, Basel, Switzerland. This article is an open access article distributed under the terms and conditions of the Creative Commons Attribution (CC BY) license (https:// creativecommons.org/licenses/by/ $4.0 /)$.

\begin{abstract}
In a foster cow system, one or more calves are reared by a foster cow. With regard to the growing rejection towards the early separation of cow and calf after calving, such alternative rearing methods with prolonged cow-calf contact are coming more into focus. Nevertheless, there is a lack of recent studies investigating the effects of suckling multiple calves on the udder health of a foster cow. The present study aimed to initially describe the status and development of the udder condition and the microbial colonisation during the foster period. Thereby, the objectives were to determine whether suckling multiple calves was associated with an increase in intramammary infections (IMI) and a deterioration of udder constitution. A total of 99 Holstein Friesian foster cows from a large organic dairy farm in eastern Germany were included in this pilot study. Each foster cow was suckled by 3-4 calves and not additionally milked. Quarter milk samples were taken for cytomicrobiological examination at the beginning and end of the approximately 3.5 months suckling period. At the same time, the udders of 91 of these foster cows were clinically examined by visual assessment and manual palpation. In both the first and second examination (E1 and E2, respectively), Corynebacterium ssp. and non-aureus staphylococci $(\mathrm{N} a \mathrm{~S})$ constituted the most frequently detected pathogen species in the 385 examined udder quarters. Classifying the quarters into mastitis categories was significantly different between the two examinations $(p=0.001)$. The number of quarters considered as healthy increased from E1 to E2 by $8.5 \%$. At the same time, the number of quarters with mastitis decreased by $2.6 \%$, the number of quarters with non-specific mastitis by $11.4 \%$ and the number of quarters with a latent infection increased by $5.4 \%$. In total, $69.4 \%$ of the 121 infected udder quarters in E1 were bacteriologically cured in E2. A cytological cure was achieved in $28.1 \%$ of the 385 quarters. Both the bacteriological and cytological cure rate were spontaneous. A new infection occurred in $23.1 \%$ of the 385 examined udder quarters and was mainly attributable to infections with Corynebacterium spp. and NaS. During the suckling period, mainly new infections occurred and amounted to $73 \%$ in relation to presumed persistent infections (18.9\%). The new infections were mainly attributable to infections with Corynebacterium spp. and $\mathrm{NaS}$. Pasteurella spp. were also found in high percentages. A total of $10.1 \%$ of the quarters showed an increase in somatic cell count (SCC) above the threshold of 100,000 cells/mL from E1 to E2, indicating a new subclinical mastitis. Regarding udder condition, significant changes during the foster period were an increase in udder skin and teat lesions, a decrease in udder oedema, an increased amount of udder quarters with a consistency considered as normal and an increase in the number of udders showing no sign of udder cleft dermatitis. Moreover, teat length, circumference, and diameter increased significantly $(p<0.05)$. In conclusion, there is a possibility that suckling multiple calves improves udder health in terms of mastitis but leads to an increased pathogen transmission at the same time, resulting in an increase in latent infections. Additionally, pathogens as Pasteurella spp., which are usually located in the upper respiratory system, could be detected in the mammary gland. The changes concerning the udder condition were manifold. However, it has not yet been conclusively clarified whether all these changes are exclusively due to calf suckling. Further investigations with a non-suckled control group are required.
\end{abstract}


Keywords: foster cows; calf rearing; intramammary infection; mastitis; udder conformation

\section{Introduction}

In a natural environment, calves suckle their mothers for six to twelve months before they are gradually weaned [1]. On the contrary, early separation of a cow and calf within $24 \mathrm{~h}$ after calving is common practice in the modern dairy industry, including in organic farming $[2,3]$. Therefore, in most cases, dairy calf rearing happens under unnatural conditions [4]. With growing public interest in animal welfare in recent years, more natural calf rearing systems with a prolonged cow-calf contact are coming more into focus $[5,6]$.

The foster cow system is an alternative calf rearing method and consists of 2-4 foster calves per foster cow, which is usually not additionally milked. The foster cow's own calf may also be among the foster calves [7]. This type of calf rearing system can be described as a compromise between natural rearing and early separation, since the calves are not reared by their biological mother, but they are able to experience natural suckling behaviour on a foster cow [4].

Thus far, most of the existing studies on the effects of fostering on cow and calf performance have focused on behavioural aspects such as the acceptance of foster calves (e.g., [8,9]) or their suckling behaviour [10]. The influence of suckling on milk yield has also been investigated in a number of studies (e.g., [11-13]). Otherwise, hardly any studies have analysed the effects of suckling on udder health of foster cows. The available literature on suckled cows mostly refers to suckling a single calf, often after milking. The transfer of these results, which are mainly positive in terms of a reduced incidence of mastitis [14-16] and a reduction in somatic cell count (SCC; $[17,18])$, to the udder health of foster cows is limited. In addition, certain studies differ considerably with regard to cattle breed, husbandry and climatic conditions, which makes a comparison difficult.

In 1974, Walsh [19] compared the milk yield and rate of infected udder quarters of 12 cows which were twice daily suckled by four calves with those of 12 machine-milked cows. The incidence of infected quarters was significantly lower in suckled cows in early lactation ( $2.1 \%$ vs. $29.2 \%$ of 48 udder quarters, respectively). Margerison et al. [13] investigated the effects of suckling multiple calves twice daily in tropical cows and demonstrated a greater reduction in SCC compared to single suckled or machine milked cows, but no differences in the incidence of clinical mastitis. In this context, the more effective emptying of the mammary gland by the calf is considered the main reason for improved udder health $[13,19]$. In contrast, more frequent emptying through more frequent milking does not appear to improve udder health. In 2010, Krömker et al. [20] compared the effects of two different milking regimes on clinical and bacteriological cure rates of 93 dairy cows with clinical and antibiotically treated mastitis. Milking cows four times daily instead of twice daily resulted in no significant difference in clinical, microbiological and full cure rate.

Fulkerson et al. [21], Thomas et al. [22] and Wagenaar and Langhout [4] could not detect any significant difference in the incidence of mastitis or SCC between multiple suckled and machine milked cows. However, there is concern that frequent suckling prevents reliable closure of the teats and thus allows pathogens to enter [4]. Many calves suckle on more than one cow, especially when their dam is not in the foster cow group $[4,10]$. In this process, a transmission of intramammary infections (IMI) between different cows via the suckling calves is discussed [23]. Nevertheless, there are no studies to date on the development of IMI due to microbial transfer between cow and calf during suckling.

Several authors noted an increased level of teat lesions related to suckling, which is probably caused by the calves' teeth [19,22]. According to Rasmussen and Larsen [24], suckled teats become rougher, although this does not result in a higher new infection rate of mastitis.

In none of the known studies was there any mention of significant negative effects of suckling on udder health. Rather, the available literature leads to the hypothesis that suck- 
ling multiple calves is not associated with a deterioration of udder health, but possibly may contribute to an improvement. However, the majority of these studies are comparatively old, methodically simplified or did not provide precise results. Therefore, more recent studies on the effects of fostering on udder health in terms of udder condition and microbial colonisation are required. In this context, the present study was conducted as a pilot study without a control group. The objectives were to compare the pathogen distribution in the mammary gland at the beginning and end of the suckling period and to determine changes in udder constitution due to multiple suckling.

\section{Materials and Methods}

\subsection{Farm and Management}

The study was conducted between May and November 2020 on a large organic dairy farm in eastern Germany with an average of 1500 milking Holstein Friesian cows producing an average of $7908 \mathrm{~kg}$ milk per year (ECM). Cows were milked twice a day in a rotary milking parlour and kept in a cubicle housing system with access to pasture between April and October. The farm was selected due to its special calf rearing method by using foster cows and the occurrence of all relevant mastitis pathogens in their cows, including contagious pathogens such as Staphylococcus (S.) aureus or Streptococcus (Sc.) agalactiae.

After calving, cow and calf were left together in a group with up to four other newborn calves and their dams. During this time, the cows were milked twice daily on a pipeline milking system and observed for good foster cow characteristics, such as allowing other calves to drink or a convenient udder conformation. Cows that had given birth to twins were preferably used as foster cows. After 3-5 days, the calves were assigned to the foster cows, while the remaining mothers returned to the milking herd. Usually three calves, occasionally four, were reared by one foster cow, which was not additionally milked during the suckling period. Before introducing the foster cow and her calves to a larger group of usually 15 other foster cows and their calves, they were given another week in small groups with two other foster cows and their associated calves to get used to each other.

Foster cows and calves were kept separate from the milking herd in an open barn with slatted flooring with a resting area made of straw and a separate area with permanent access for calves only. All foster cows were checked daily by the staff for any signs of clinical mastitis such as reddening, swelling, pain, increased heat of the udder or abnormal milk appearance. The suckling period ended at about 3.5 months. Prior to that, the foster calves were gradually weaned. Subsequently, the foster cows returned to the milking herd and were milked until the following dry period.

\subsection{Study Design and Data Collection}

Initially, a total of 124 primiparous and multiparous foster cows of the Holstein Friesian breed were included in the study, which all calved between May and August 2020. Lactation numbers varied from one to eight, with the majority of foster cows being in their second to fourth lactation (99 cows) and twelve being heifers. From 99 of these foster cows, quarter milk samples were taken from all four quarters for cytomicrobiological diagnosis at the beginning and end of the suckling period. There were no selection criteria except calving in the mentioned period.

The udder of 91 foster cows was examined twice during the suckling period. A group of 28 cows was first examined between days 28 and 38 after calving and the second examination was conducted eight weeks later. Another 63 cows were examined within the first 12-13 days postpartum. After 10-13 weeks, shortly before weaning the calves, a second examination of the udder occurred. A major part of the examinations was conducted by a veterinarian during the regular visits, several cows were examined by an employed farmer after an interobserver training with the veterinarian. 


\subsection{Examination of the Udder}

The clinical examination of the udder was based on the examination of Grunert [25] and included visual inspection and manual palpation of the mammary gland. In this context, findings regarding the condition of the entire udder, individual udder quarters and the teats were collected. Every examination started with an evaluation of the entire udder concerning size, position and conformation and the subsequent assigning to a category (e.g., belly-thigh udder or milking-machine udder). The individual udder quarters were checked for swelling or atrophy. Every single teat was assessed regarding shape of the entire teat (normal versus others), teat end (normal versus others), height above the ankle (higher versus same height versus lower), length and diameter one centimetre above the apex. The reference values for the teat length and teat diameter were those recorded by Haverkamp et al. [26]. Teat injuries were also noted. Furthermore, hyperkeratosis around the teat orifice was visually examined and classified as follows: $\mathrm{N}=$ no ring, $\mathrm{S}=$ smooth ring, $\mathrm{R}=$ rough ring, $\mathrm{VR}=$ very rough ring [27]. Surplus teats and incontinentia lactis were noted likewise. The udder skin was examined for skin colour (normal versus others), injuries and circumferential multiplications. The extent of udder cleft dermatitis (UCD) was classified by using a score: $0=$ no UCD , $1=$ reddened skin, $2=$ skin abrasion or scabs, $3=$ wound, $4=$ wound larger than a hen's egg.

The second part of every examination was manual palpation of the udder. The udder skin was checked for temperature (normal versus increased heat/cold) and oedema. During palpation of the mammary gland, a normal and a coarse knotted or hardened consistency of the glandular tissue was distinguished. In this context, 'normal' was defined as a soft, fine to coarse grained consistency. The continuity of the teats and teat cistern was controlled by using the cistern and roll grip as established by Grunert [25]. In the cistern grip, the teat is indented at the teat base, the transition to the glandular cistern, with the fingertip. The roll grip describes rolling the teat between two fingers to feel the mucosa of the teat cistern [25]. Udder lymph nodes were checked for swelling. An overview of the parameters included in the examinations are found in Table 1.

\subsection{Quarter Milk Samples}

The quarter milk samples were aseptically collected in sterile plastic tubes by the veterinarian and the employed farmer at the beginning and the end of the suckling period. The test tubes contained boric acid as a reserving agent. Before each collection, the first milk squirls were discarded and the apex of the teat was cleaned with $70 \%$ ethanol. Disposable gloves were worn during sampling and disinfected after each cow. The collected milk samples were either transported by the veterinarian in a cooling box or sent by the employed farmers by mail to the departmental laboratory of the University of Applied Sciences and Arts Hannover, Germany for further analysis.

\subsection{Laboratory Analyses}

The examination of the quarter milk samples was conducted in the laboratory following the guidelines of the German Veterinary Medical Association [28].

First, $10 \mu \mathrm{L}$ of each sample were plated on esculin blood agar (5\% defibrinated sheep blood, Oxoid Deutschland GmbH, Wesel, Germany) in duplicate and aerobically incubated at $37^{\circ} \mathrm{C}$. The blood agar plates were analysed after 24 and $48 \mathrm{~h}$. A first classification was based on Gram-straining, colony and cell morphology, haemolysis and esculin hydrolysis. Further differentiation was carried out using various tests.

The bacteriological results were confirmed by matrix-assisted laser desorption timeof-flight mass-spectrometry (MALDI-TOF, Bruker Daltonics GmbH \& Co. KG, Bremen, Germany) with a direct transfer method without acid extraction, using the MBT Compass Library (Revision F, MBT 84668 MSP Library, Bruker Daltonics GmbH \& Co. KG, Bremen, Germany). The cut-off level was $>1.7$ for species identification [29].

SomaScopeTM Smart (Delta Instruments B.V., Drachten, The Netherlands) was used to determine the SCC. 
Table 1. Parameters included in the examination of the udder.

\begin{tabular}{|c|c|c|}
\hline Parameter & Recording Method & Score/Category \\
\hline Udder shape & Visual & $\begin{array}{l}\text { Belly-thigh udder versus } \\
\text { milking-machine udder versus other }\end{array}$ \\
\hline Teat shape & Visual & Normal versus other \\
\hline Teat length (mm) & Measuring & From the base of the teat to the teat tip \\
\hline Teat diameter (mm) & Measuring & $1 \mathrm{~cm}$ above the teat tip \\
\hline Teat end position & Visual & $\begin{array}{c}\text { In relation to the ankle: higher versus } \\
\text { same height versus lower }\end{array}$ \\
\hline Teat end shape & Visual & Normal versus other \\
\hline Teat end hyperkeratosis & Visual & $\begin{array}{c}1=\text { no ring } \\
2=\text { smooth ring } \\
3=\text { rough ring } \\
4=\text { very rough ring }\end{array}$ \\
\hline Surplus teats & Visual & Yes versus no \\
\hline Incontinentia lactis & Visual & Yes versus no \\
\hline Colour of the udder skin & Visual & Normal versus other \\
\hline $\begin{array}{l}\text { Udder cleft dermatitis } \\
\text { (UCD) }\end{array}$ & Visual & $\begin{array}{c}0=\text { no signs of UCD } \\
1=\text { reddened skin } \\
2=\text { skin abrasion or scabs } \\
3=\text { wound } 4=\text { wound larger than a } \\
\text { hen's egg }\end{array}$ \\
\hline Temperature of udder skin & Manual & Normal versus other \\
\hline Udder oedema & Manual & Yes versus no \\
\hline $\begin{array}{l}\text { Consistency of the } \\
\text { mammary gland tissue }\end{array}$ & Manual & $\begin{array}{l}\text { Normal versus partly knotted versus } \\
\text { coarse knotted to hardened }\end{array}$ \\
\hline Cistern grip & Manual & Normal versus other \\
\hline Roll grip & Manual & Normal versus other \\
\hline Udder lymph nodes & Visual & Normal versus other \\
\hline
\end{tabular}

\subsection{Definitions}

The results of the laboratory analyses were classified using the following definitions according to the guidelines of the German Veterinary Association [30]: a healthy quarter described a quarter with neither a pathogen detection nor an SCC above 100,000 cells $/ \mathrm{mL}$. A latent infection was defined as a positive pathogen detection combined with an SCC below 100,000 cells $/ \mathrm{mL}$. In contrast, non-specific mastitis was defined as a negative pathogen detection but an increased SCC $(\geq 100,000$ cells $/ \mathrm{mL})$. In the case of mastitis, both the pathogen detection was positive, and the SCC was elevated. If clinical signs, such as swelling, reddening or abnormal milk appearance, were also present, the diagnosis was clinical mastitis.

A quarter was considered as bacteriologically cured if a pathogen detected in examination 1 (E1) was not detectable in examination 2 (E2). Cytological cure was defined as a decrease in the SCC from $\geq 100,000$ cells $/ \mathrm{mL}$ in $\mathrm{E} 1$ to $<100,000$ cells $/ \mathrm{mL}$ in E2. A new infection occurred if a pathogen was cultured in E2 which had not been present in E1. Conversely, a persistent infection was identified if the same pathogen species was found both in E1 and E2. A new subclinical mastitis was defined as an increase in the SCC from $<100,000$ cells $/ \mathrm{mL}$ in $\mathrm{E} 1$ to $\geq 100,000$ cells $/ \mathrm{mL}$ in $\mathrm{E} 2$. 


\subsection{Statistical Analyses}

The data were collected in Microsoft Excel 2016 (Microsoft Corporation, Washington, Redmond, WA, USA). For statistical analysis of the dataset, the program SPSS (26.0, IBM Corp., Armonk, NY, USA) with the udder quarter as a statistical unit was used. The tested null hypothesis was that there was no significant difference in pathogen distribution and udder constitution between the two examination times. Therefore, the frequency distributions of these nominal data were compared using $\chi^{2}$ tests (Chi-square tests). Statistical significance was given at a $p$ value $<0.05$. Normally distributed data (teat length, teat circumference and teat diameter) were further examined with the Student's $t$ test for paired samples in univariable analysis. The SCC was transformed to the somatic cell score (SCS) for statistical analysis using the formula:

$$
\mathrm{SCS}=\log _{2}(\mathrm{SCC} / 100,000)+3
$$

Subsequently, the $t$ test for paired samples was conducted to test whether the mean values of SCS differed between the two examinations. For both tests, a $p$ value $<0.05$ was considered significant.

\section{Results}

\subsection{Numbers of Cows and Quarters}

A total of 124 foster cows with 486 lactating udder quarters were part of the first examination shortly after calving. As 25 of these cows left the foster cow-calf group before the final examination due to illness (mainly mastitis) or death, 99 foster cows finally remained. Furthermore, only lactating udder quarters were considered which resulted in 385 udder quarters out of 99 cows finally being sampled twice.

The examination of the udder was conducted twice on 91 cows at the beginning and the end of the suckling period.

\subsection{Bacteriological Examination}

The detailed pathogen distribution of the evaluated quarter milk samples is shown in Table 2. A distinction was made between all 124 cows examined at the beginning (E1a) and those 99 cows that were still in the foster cow group at the final examination (E1b and E2).

For better comparability, the following descriptions focus on the 99 remaining foster cows with 385 examined quarters in total. In the first examination, in $31.4 \%(\mathrm{n}=121)$ of the quarters, mastitis-associated pathogens were detected. A total of $62.9 \%(\mathrm{n}=242)$ showed no bacterial growth on blood agar and $5.7 \%(n=22)$ were contaminated. At the end of the suckling period, the percentage of quarters with an IMI amounted to $31.7 \%(\mathrm{n}=122)$. In $58.4 \%(\mathrm{n}=225)$ of the samples, no bacterial growth was detectable and $9.9 \%(n=38)$ were contaminated. Thus, $7 \%$ fewer quarters showed no bacterial growth at the end of the suckling period compared to the first days after calving. The distribution of pathogens was significantly different between the two examination times $(p<0.001)$. In both E1b and E2, the most frequently detected pathogens were opportunistic pathogens such as Corynebacterium spp. (E1b: $\mathrm{n}=37,9.6 \%, \mathrm{E} 2: \mathrm{n}=50,13 \%$ ) and nonaureus staphylococci ( $\mathrm{NaS}$ ) (E1b: $\mathrm{n}=29,7.5 \%, \mathrm{E} 2: \mathrm{n}=24,6.2 \%)$. Moreover, Pasteurella spp. $(\mathrm{n}=13,3.4 \%)$ were found in high percentages in the final examination. Mixed infections with two different pathogens detected in one sample also accounted for high percentages with $4.9 \%$ in E1b ( $\mathrm{n}=19)$ and $3.1 \%$ in E2 ( $\mathrm{n}=12)$, respectively. Cow-associated pathogens such as S. aureus, Sc. agalactiae and Trueperella (T.) pyogenes were involved in $0 \%(\mathrm{E} 1 \mathrm{~b}$, $\mathrm{n}=0)$ and $4.1 \%(E 2, \mathrm{n}=5)$ of the infections. These results showed a slightly increased contribution of cow-associated pathogens at the end of the suckling period compared to the examination shortly after calving. In contrast, the proportion of environmentassociated pathogens (coliform bacteria, Enterococcus spp., Sc. uberis, Sc. dysgalactiae, Aerococcus viridans, Lactococcus spp. and Pseudomonas spp.) decreased. Furthermore, Table 2 shows the ratio of persistent infections to new infections. Of the 122 infected udder 
quarters, $23(18.9 \%)$ were presumably persistently infected with the same pathogen species in E1b and E2. These were infections with Corynebacterium spp. and NaS. A total of 89 (73\%) quarters were newly infected with a different pathogen species in E2 than in E1b. This applies especially to IMI caused by Pasteurella spp. which were exclusively due to new infections. Infections with cow-associated pathogens were also mainly new infections. In ten cases $(8.2 \%)$ a specification was not possible due to contamination of the sample.

Table 2. Pathogens isolated from quarter milk samples at the first and second examination.

\begin{tabular}{|c|c|c|c|c|c|}
\hline \multirow{2}{*}{ Pathogen } & \multicolumn{5}{|c|}{ Number (\%) of Isolated Pathogens } \\
\hline & E1a $^{1}$ & E1b ${ }^{2}$ & E2 & Persistent Infections ${ }^{3}$ & New Infections ${ }^{4}$ \\
\hline Streptococcus uberis & $1(0.2)$ & $1(0.3)$ & $2(0.5)$ & $0(0)$ & $2(100)$ \\
\hline $\mathrm{NaS}{ }^{5}$ & $34(7.0)$ & $29(7.5)$ & $24(6.2)$ & $3(12.5)$ & $20(83.3)$ \\
\hline Staphylococcus aureus & $0(0)$ & $0(0)$ & $3(0.8)$ & $0(0)$ & $3(100)$ \\
\hline Streptococcus dysgalactiae & $0(0)$ & $0(0)$ & $2(0.5)$ & $0(0)$ & $1(50)$ \\
\hline Trueperella pyogenes & $0(0)$ & $0(0)$ & $2(0.5)$ & $0(0)$ & $2(100)$ \\
\hline Escherichia coli & $8(1.6)$ & $8(2.1)$ & $0(0)$ & $0(0)$ & $0(0)$ \\
\hline Coliforms & $8(1.6)$ & $5(1.3)$ & $0(0)$ & $0(0)$ & $0(0)$ \\
\hline Klebsiella spp. & $2(0.4)$ & $2(0.5)$ & $1(0.3)$ & $0(0)$ & $1(100)$ \\
\hline Bacillus spp. & $3(0.6)$ & $3(0.8)$ & $0(0)$ & $0(0)$ & $0(0)$ \\
\hline Corynebacterium spp. & $44(9.1)$ & $37(9.6)$ & $50(13)$ & $20(40)$ & $27(54)$ \\
\hline Enterococcus spp. & $4(0.8)$ & $4(1.0)$ & $2(0.5)$ & $0(0)$ & $2(100)$ \\
\hline Pseudomonas spp. & $2(0.4)$ & $2(0.5)$ & $0(0)$ & $0(0)$ & $0(0)$ \\
\hline Other streptococci & $6(1.2)$ & $3(0.8)$ & $4(1.0)$ & $0(0)$ & $3(75)$ \\
\hline Lactic acid bacteria & $9(1.9)$ & $6(1.6)$ & $0(0)$ & $0(0)$ & $0(0)$ \\
\hline Pasteurella spp. & $0(0)$ & $0(0)$ & $13(3.4)$ & $0(0)$ & $13(100)$ \\
\hline Others ${ }^{6}$ & $3(0.6)$ & $2(0.5)$ & $7(1.9)$ & $0(0)$ & $7(100)$ \\
\hline Mixed & $21(4.3)$ & $19(4.9)$ & $12(3.1)$ & $0(0)$ & $8(66.7)$ \\
\hline Contaminated $^{7}$ & $31(6.4)$ & $22(5.7)$ & $38(9.9)$ & $0(0)$ & $0(0)$ \\
\hline In total & $\begin{array}{c}145 \\
(29.8)\end{array}$ & $\begin{array}{c}121 \\
(31.4)\end{array}$ & $\begin{array}{c}122 \\
(31.7)\end{array}$ & $23(18.9)$ & $89(73)$ \\
\hline No specific growth ${ }^{8}$ & $\begin{array}{c}310 \\
(63.8)\end{array}$ & $\begin{array}{c}242 \\
(62.9)\end{array}$ & $\begin{array}{c}225 \\
(58.4)\end{array}$ & & \\
\hline
\end{tabular}

${ }^{1}$ All quarters examined in E1. ${ }^{2}$ All quarters examined in E1 which were still present in E2. ${ }^{3}$ Persistent infections were defined as an IMI with the same pathogen species/genus in E1 and E2. ${ }^{4} \mathrm{New}$ Infections were defined as an IMI when a different pathogen species/genus occurred in E2 than in E1. ${ }^{5}$ Non-aureus staphylococci. ${ }^{6}$ Aerocococcus viridans, Mannheimia haemolytica. ${ }^{7}$ More than two pathogens detected in one sample. ${ }^{8}$ No bacterial growth on blood agar.

\subsection{Classification of Udder Health}

Figure 1 shows the classification of udder health according to the guidelines of the German Veterinary Association [30]. As mentioned above, this figure also distinguishes between all examined cows (E1a) and those present at the end of the suckling period (E1b, E2). In addition, only those quarters are listed in E1b and E2 for which a diagnosis could be made in both examinations. In E1b, 32.5\% $(n=125)$ of the 385 remaining udder quarters were considered as healthy. A total of $11.2 \%(n=43)$ of the udder quarters showed a latent infection, $19.2 \%(n=74)$ non-specific mastitis and $10.9 \%(n=42)$ mastitis. In contrast, $41 \%(n=158)$ healthy udder quarters were detectable in E2. Another $16.6 \%(n=64)$ of the quarters accounted for a latent infection, $7.8 \%(n=30)$ for non-specific mastitis and $8.3 \%(n=32)$ for mastitis. Clinical mastitis with an abnormal milk appearance or other clinical signs was detectable in no quarter in E1b and in one quarter in E2. Of 101 (26.2\%) udder quarters, a diagnosis in either E1b or E2 was not possible due to missing SCC result or contamination. Classifying the quarters into mastitis categories was significantly different between the two examinations $(p=0.001)$. Thus, $8.5 \%$ more quarters were determined as healthy in E2 compared to E1b. At the same time, the number of non-specific and mastitis cases decreased. The number of quarters with a latent infection increased by $5.4 \%$. 


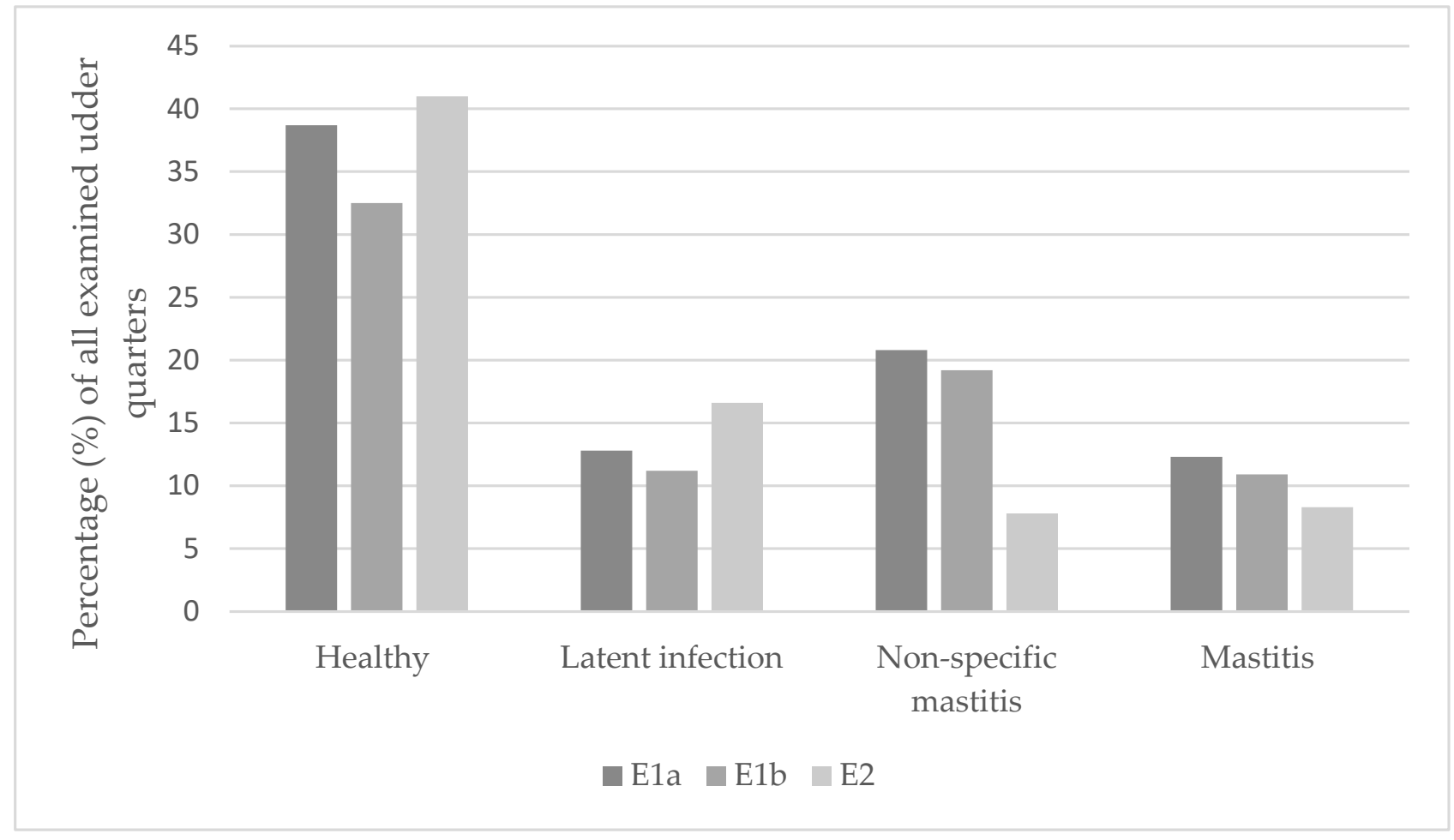

Figure 1. Classification of the examined udder quarters into the different categories of udder health. E1a = all quarters examined in E1; E1b = all quarters examined in E1 which were still present in E2.

In the following sections, E1 only refers to the results of the 99 cows that were sampled twice. A distinction between E1a and E1b is no longer made. The detailed distribution of pathogens associated with latent infections and mastitis is shown in Tables 3 and $4 . \mathrm{NaS}$ and Corynebacterium spp. were the main pathogens involved in latent infections both in E1 and E2. In particular, the percentage of Corynebacterium spp. increased (E1 37.2\%, E2: 56.3\%) and was mainly due to new infections (58.3\%). With regard to mastitis, Pasteurella spp. were the pathogen group with the highest increase from $0 \%(n=0)$ in E1 up to $28.1 \%(n=9)$ in E2. NaS and Corynebacterium spp. constituted the second most detected pathogen groups in the final examination and showed a decreased proportion from E1 to E2.

\subsection{Bacteriological and Cytological Cure}

Table 5 presents the spontaneous bacteriological and cytological cure rates of the 385 twice-examined quarters in relation to the pathogens involved. In this context, no antimicrobial or other treatment of the cows occurred during the foster period. A total of $84(69.4 \%)$ out of 121 infected udder quarters achieved a bacteriological cure between the two examinations. The bacteriological cure rate was significantly associated with the diagnosis made in E1 $(p<0.001)$. As mentioned above, Corynebacterium spp. and NaS constituted the most prevalent pathogen groups in E1. Of the $37(9.6 \%)$ quarters infected with Corynebacterium spp., 16 (43.2\%) quarters were bacteriologically cured in E2. In the case of NaS, bacteriological cure was achieved in $25(86.2 \%)$ out of 29 infected quarters. No bacteriological cure was detected in $24(19.8 \%)$ of the 121 infected udder quarters. However, the quarters without any bacterial growth $(n=242)$ and contaminated samples $(n=22)$ were not included. 
Table 3. Detailed distribution of pathogens associated with latent infections.

\begin{tabular}{ccccc}
\hline \multirow{2}{*}{ Pathogen } & \multicolumn{4}{c}{ Number (\%) of Isolated Pathogens } \\
\cline { 2 - 5 } & $\mathbf{E 1}^{\mathbf{1}}$ & $\mathbf{E 2}$ & Persistent Infections $\mathbf{~}^{2}$ & New Infections ${ }^{\mathbf{3}}$ \\
\hline Streptococcus uberis & $1(2.3)$ & $0(0)$ & $0(0)$ & $0(0)$ \\
NaS & $8(18.6)$ & $15(23.4)$ & $2(13.3)$ & $13(86.7)$ \\
Staphylococcus aureus & $0(0)$ & $1(1.6)$ & $0(0)$ & $1(100)$ \\
Streptococcus & $0(0)$ & $0(0)$ & $0(0)$ & $0(0)$ \\
dysgalactiae & $0(0)$ & $0(0)$ & $0(0)$ & $0(0)$ \\
Trueperella pyogenes & $1(2.3)$ & $0(0)$ & $0(0)$ & $0(0)$ \\
Escherichia coli & $1(2.3)$ & $0(0)$ & $0(0)$ & $0(0)$ \\
Coliforms & $0(0)$ & $0(0)$ & $0(0)$ & $0(0)$ \\
Klebsiella spp. & $3(7)$ & $0(0)$ & $0(0)$ & $0(0)$ \\
Bacillus spp. & $16(37.2)$ & $36(56.3)$ & $15(41.7)$ & $1(100)$ \\
Corynebacterium spp. & $1(2.3)$ & $1(1.6)$ & $0(0)$ & $0(0)$ \\
Enterococcus spp. & $0(0)$ & $0(0)$ & $0(0)$ & $1(100)$ \\
Pseudomonas spp. & $1(2.3)$ & $1(1.6)$ & $0(0)$ & $0(0)$ \\
Other streptococci & $3(7)$ & $0(0)$ & $0(0)$ & $0(0)$ \\
Lactic acid bacteria & $0(0)$ & $0(0)$ & $0(0)$ & $7(100)$ \\
Pasteurella spp. & $2(4.7)$ & $7(11)$ & $0(0)$ & $3(100)$ \\
Others 5 & $6(14)$ & $3(4.7)$ & $0(0)$ & $47(73.4)$ \\
Mixed & $43(100)$ & $64(100)$ & $17(26.6)$ & N
\end{tabular}

${ }^{1}$ First milk sample of the 99 remaining cows. ${ }^{2}$ Persistent infections were defined as an IMI with the same pathogen species/genus in E1 and E2. ${ }^{3} \mathrm{New}$ infections were defined as an IMI with a different pathogen species/genus in E1 than in E2. ${ }^{4}$ Non-aureus staphylococci. ${ }^{5}$ Aerococcus viridans, Mannheimia haemolytica.

Table 4. Detailed distribution of pathogens associated with mastitis.

\begin{tabular}{ccccc}
\hline \multirow{2}{*}{ Pathogen } & \multicolumn{4}{c}{ Number (\%) of Isolated Pathogens } \\
\cline { 2 - 5 } & $\mathbf{E 1}^{\mathbf{1}}$ & E2 & ${\text { Persistent Infections }{ }^{2}}$ & New Infections $^{3}$ \\
\hline Streptococcus uberis & $0(0)$ & $1(3.1)$ & $0(0)$ & $1(100)$ \\
NaS & $15(35.7)$ & $6(18.8)$ & $1(16.7)$ & $5(83.3)$ \\
Staphylococcus aureus & $0(0)$ & $2(6.3)$ & $0(0)$ & $2(100)$ \\
Streptococcus & $0(0)$ & $1(3.1)$ & $0(0)$ & $1(100)$ \\
dysgalactiae & $0(0)$ & $2(6.3)$ & $0(0)$ & $2(100)$ \\
Trueperella pyogenes & $5(11.9)$ & $0(0)$ & $0(0)$ & $0(0)$ \\
Escherichia coli & $2(4.8)$ & $0(0)$ & $0(0)$ & $0(0)$ \\
Coliforms & $1(2.4)$ & $1(3.1)$ & $0(0)$ & $1(100)$ \\
Klebsiella spp. & $0(0)$ & $0(0)$ & $0(0)$ & $2(0)$ \\
Bacillus spp. & $12(28.6)$ & $4(12.5)$ & $2(50)$ & $1(100)$ \\
Corynebacterium spp. & $2(4.8)$ & $1(3.1)$ & $0(0)$ & $0(0)$ \\
Enterococcus spp. & $0(0)$ & $0(0)$ & $0(0)$ & $2(100)$ \\
Pseudomonas spp. & $1(2.4)$ & $2(6.3)$ & $0(0)$ & $0(0)$ \\
Other streptococci & $1(2.4)$ & $0(0)$ & $0(0)$ & $9(100)$ \\
Lactic acid bacteria & $0(0)$ & $9(28.1)$ & $0(0)$ & $0(0)$ \\
Pasteurella spp. & $0(0)$ & $0(0)$ & $0(0)$ & $3(100)$ \\
Others 5 & $3(7.1)$ & $3(9.4)$ & $0(0)$ & $29(90.6)$ \\
Mixed & $42(100)$ & $32(100)$ & $3(9.4)$ & \\
\hline In total & & &
\end{tabular}

${ }^{1}$ First milk sample of the 99 remaining cows. ${ }^{2}$ Persistent infections were defined as an IMI with the same pathogen species/genus in E1 and E2. ${ }^{3}$ New infections were defined as an IMI with a different pathogen species/genus in E1 than in E2. ${ }^{4}$ Non-aureus staphylococci. ${ }^{5}$ Aerococcus viridans, Mannheimia haemolytica. 
A cytological cure was detectable in $108(28.1 \%)$ out of 385 udder quarters and significantly associated with the diagnosis made in E1 $(p<0.001)$. The largest proportion of the cytological cure rate was attributable to non-specific mastitis and corresponding negative pathogen detection $(n=65,60.2 \%)$. A total of $13(44.8 \%)$ of the quarters infected with NaS in E1 were cytologically cured in E2. For Corynebacterium spp., 9 (24.3\%) of the 37 infected quarters in E1 reached an SCC below 100,000 cells $/ \mathrm{mL}$ in E2. Moreover, the mean values of the SCS based on the SCC differed significantly between the two examinations $(p<0.001)$ and showed a decrease from E1 to E2.

\subsection{New Subclinical Mastitis}

The detailed pathogen distribution according to the new subclinical mastitis rate is given in Table 6. A total of 39 quarters (10.1\%) showed an increase in SCC above the threshold of 100,000 cells $/ \mathrm{mL}$ in the second examination, defined as new subclinical mastitis. This was mainly associated with no growth on blood agar $(n=21 / 225$, $53.8 \%$ ). The other major part of new subclinical mastitis cases derived from quarters with NaS ( $\mathrm{n}=5 / 24,12.8 \%)$, Pasteurella spp. ( $\mathrm{n}=4 / 13,10.3 \%)$ as well as other streptococci ( $\mathrm{n}=2 / 4,5.1 \%)$ and Corynebacterium spp. ( $\mathrm{n}=2 / 50,5.1 \%)$. The development of a new subclinical mastitis was significantly associated with the first diagnosis $(p<0.001)$.

Table 5. Spontaneous bacteriological and cytological cure rates of the detected pathogens.

\begin{tabular}{|c|c|c|c|c|c|c|}
\hline \multirow{2}{*}{ Pathogen } & \multicolumn{3}{|c|}{ Bacteriological Cure } & \multicolumn{3}{|c|}{ Cytological Cure } \\
\hline & $\mathbf{n}$ & $\% 1$ & $\% 2$ & $\mathbf{n}$ & $\%^{1}$ & $\%^{2}$ \\
\hline Streptococcus uberis & $1 / 1$ & 100 & 1.2 & $0 / 1$ & 0 & 0 \\
\hline $\mathrm{NaS}{ }^{3}$ & $25 / 29$ & 86.2 & 29.8 & $13 / 29$ & 44.8 & 12 \\
\hline Staphylococcus aureus & $0 / 0$ & 0 & 0 & $0 / 0$ & 0 & 0 \\
\hline Streptococcus dysgalactiae & $0 / 0$ & 0 & 0 & $0 / 0$ & 0 & 0 \\
\hline Trueperella pyogenes & $0 / 0$ & 0 & 0 & $0 / 0$ & 0 & 0 \\
\hline Escherichia coli & $8 / 8$ & 100 & 9.5 & $4 / 8$ & 50 & 3.7 \\
\hline Coliforms & $5 / 5$ & 100 & 6 & $2 / 5$ & 40 & 1.9 \\
\hline Klebsiella spp. & $2 / 2$ & 100 & 2.4 & $1 / 2$ & 50 & 0.9 \\
\hline Bacillus spp. & $3 / 3$ & 100 & 3.6 & $0 / 3$ & 0 & 0 \\
\hline Corynebacterium spp. & $16 / 37$ & 43.2 & 19 & $9 / 37$ & 24.3 & 8.3 \\
\hline Enterococcus spp. & $3 / 4$ & 23.1 & 3.6 & $1 / 4$ & 25 & 0.9 \\
\hline Pseudomonas spp. & $1 / 2$ & 50 & 1.2 & $0 / 2$ & 0 & 0 \\
\hline Other streptococci & $3 / 3$ & 100 & 3.6 & $1 / 3$ & 33.3 & 0.9 \\
\hline Lactic acid bacteria & $5 / 6$ & 83.3 & 6 & $1 / 6$ & 16.7 & 0.9 \\
\hline Pasteurella spp. & $0 / 0$ & 0 & 0 & $0 / 0$ & 0 & 0 \\
\hline Others 4 & $2 / 2$ & 100 & 2.4 & $0 / 2$ & 0 & 0 \\
\hline Mixed & $10 / 19$ & 52.6 & 11.9 & $5 / 19$ & 26.3 & 4.6 \\
\hline Contaminated $^{5}$ & & & & $6 / 22$ & 27.3 & 5.6 \\
\hline No specific growth ${ }^{6}$ & & & & $65 / 242$ & 26.9 & 60.2 \\
\hline In total & $84 / 121$ & 69.4 & 100 & $108 / 385$ & 28.1 & 100 \\
\hline
\end{tabular}

${ }^{1}$ Proportion of all cases caused by the pathogen group. ${ }^{2}$ Proportion of cases of all bacteriological/cytological cured cases. ${ }^{3}$ Non-aureus staphylococci. ${ }^{4}$ Aerococcus viridans, Mannheimia haemolytica. ${ }^{5}$ More than two different pathogens were detected in one sample. ${ }^{6}$ No specific growth on blood agar. 
Table 6. New subclinical mastitis rate of the detected pathogens.

\begin{tabular}{|c|c|c|c|}
\hline \multirow{2}{*}{ Pathogen } & \multicolumn{3}{|c|}{ New Subclinical Mastitis } \\
\hline & $\mathbf{n}$ & $\% 1$ & $\%{ }^{2}$ \\
\hline Streptococcus uberis & $0 / 2$ & 0 & 0 \\
\hline $\mathrm{NaS}{ }^{3}$ & $5 / 24$ & 20.8 & 12.8 \\
\hline Staphylococcus aureus & $1 / 3$ & 33.3 & 2.6 \\
\hline Streptococcus dysgalactiae & $0 / 2$ & 0 & 0 \\
\hline Trueperella pyogenes & $0 / 2$ & 0 & 0 \\
\hline Escherichia coli & $0 / 0$ & 0 & 0 \\
\hline Coliforms & $0 / 0$ & 0 & 0 \\
\hline Klebsiella spp. & $1 / 1$ & 100 & 2.6 \\
\hline Bacillus spp. & $0 / 0$ & 0 & 0 \\
\hline Corynebacterium spp. & $2 / 50$ & 4 & 5.1 \\
\hline Enterococcus spp. & $1 / 2$ & 50 & 2.6 \\
\hline Pseudomonas spp. & $0 / 0$ & 0 & 0 \\
\hline Other streptococci & $2 / 4$ & 50 & 5.1 \\
\hline Lactic acid bacteria & $0 / 0$ & 0 & 0 \\
\hline Pasteurella spp. & $4 / 13$ & 31 & 10.3 \\
\hline Others 4 & $0 / 7$ & 0 & 0 \\
\hline Mixed & $1 / 12$ & 8 & 2.6 \\
\hline Contaminated $^{5}$ & $1 / 38$ & 2.6 & 2.6 \\
\hline No specific growth ${ }^{6}$ & $21 / 229$ & 9.3 & 53.8 \\
\hline In total & $39 / 385$ & 10.1 & 100 \\
\hline
\end{tabular}

${ }^{1}$ Proportion of all cases caused by the pathogen group. ${ }^{2}$ Proportion of cases of all bacteriologically/cytologically cured cases. ${ }^{3}$ Non-aureus staphylococci. ${ }^{4}$ Aerococcus viridans, Mannheimia haemolytica. ${ }^{5}$ More than two different pathogens were detectable in one sample. ${ }^{6}$ No specific growth on blood agar.

\subsection{Udder Examination}

From the first to the second examination, the most prevalent findings concerning the udder were a reduced number of milking machine udders (E1: $n=17,18.7 \%, E 2: n=7,7.7 \%$ ), an increase in the number udder skin lesions (E1: $\mathrm{n}=4,4.4 \%, \mathrm{E} 2 \mathrm{n}=17,18.7 \%)$, an increase in the number of udders showing no sign of udder cleft dermatitis (E1: $n=66,72.5 \%$, $\mathrm{E} 2: \mathrm{n}=76,83.5 \%$ ) and a reduction in cases of udder oedema (E1: $n=30,33 \% \mathrm{E} 2 \mathrm{n}=4,4.4 \%$ ). The consistency of more udder quarters was considered as normal in E2 (e.g., left front quarter: $\mathrm{n}=53(58.2 \%)$ in E1, $\mathrm{n}=72(79.1 \%)$ in E2). Thereby, the distribution of the examined udder quarters in the categories udder skin lesions, udder oedema, consistency of the mammary gland tissue and UCD was significantly different between the two examination times $(p<0.05)$. Changes were also observed regarding the condition of the teats in particular. In E2, a significant increased number of teats showed lesions (E1: $n=15,16.4 \%, E 2: n=32,35.2 \%$, $p<0.001)$. In addition, increases in teat length, teat circumference and teat diameter were determined and considered as statistically significant $(p<0.05)$. More teats had a teat end position below the hock compared to E1. This change was significant for the left front quarter $(p=0.044)$.

\section{Discussion}

This study was conducted as a cross-sectional study against the background of an increasing demand for more animal welfare and more natural livestock farming. The foster cow system represents an alternative calf rearing method to combine these requirements with economic- and productivity-related aspects. Thus far, there is little literature available on the impact of such a rearing system on udder health. In this context, the present study served as a pilot study with an orientating character and aimed to gain a first impression on the effects of suckling multiple calves on the mammary gland of a foster cow. For this reason, a control group was not used. Furthermore, to the best of our knowledge, this organic dairy farm is the only large farm in Germany practising calf rearing in a foster cow system. A conventional control group was therefore not available. 
The date of the first sampling was as close as possible to the time when the foster cow was brought together with her calves, but after completion of the colostrum period. Therefore, the samples were not taken earlier than three days after calving to prevent the colostrum from influencing the results. The second sampling was conducted shortly before the end of the suckling period, which meant 8-13 weeks after the first one.

\subsection{Pathogen Distribution}

Corynebacterium ssp. and $\mathrm{NaS}$ constituted the most frequently detected pathogen species in both examinations. In contrast, major contagious pathogens were isolated only to a small extent. The high percentages of $\mathrm{NaS}$ and Corynebacterium spp. agree with the findings of previous studies and may indicate that the pathogen distribution in foster cows is similar to that of milked cows in early lactation. Both Kiesner et al. [31] and Nitz et al. [32] examined milk samples of early lactating dairy cows. As in the present study, Kiesner et al. [31] focused on organic dairy farms in Germany. In this previous study, the quarter milk samples were taken at dry off and at two different times after calving (5-12 days postpartum and seven days later). The results of the postpartum samples were paired and showed that $83(33.2 \%)$ of 250 cows were infected with NaS, whereas $61(24.4 \%)$ of 250 cows were infected with Corynebacterium spp. Nitz et al. [32] examined 960 quarter milk samples from dairy cows at dry off as well as $3 \pm 1$ days and $17 \pm 3$ days postpartum. At both times of sampling after calving, $\mathrm{NaS}$ constituted the most common pathogen group and were isolated in 48 of 960 (5\%) quarters $3 \pm 1$ days and in 83 of 960 (8.6\%) quarters $17 \pm 3$ days after calving, respectively. Different from the present study, the authors also found S. aureus and Sc. uberis in high percentages in the quarter milk samples after calving. Corynebacterium spp. were detected in 10 (1\%) and 15 (1.6\%) of 960 quarters, respectively. In this context, they found a correlation in heifers with a high milk yield recorded in the first dairy herd improvement test postpartum and a higher risk for an IMI caused by NaS and coryneforms [33]. González-Sedano et al. [16] compared the effect of residual calf suckling after milking with a non-suckled group in dual-purpose cows in Mexico. In both groups, NaS were the most frequently detected pathogen species, followed by $S$. aureus and Pseudomonas aeruginosa. They considered the presence of $\mathrm{NaS}$ in various structures of the mammary gland as a possible reason for the high prevalence [34]. Nevertheless, both the breed and the husbandry of these cows as well as the climatic conditions in this previous study differ considerably from those in the present study. The comparability of the results is limited. In addition, contaminated samples should be kept in mind, which may have influenced the pathogen distribution in the present study.

The second examination at the end of the suckling period showed a high prevalence of Pasteurella ssp., which were often associated with subclinical mastitis. Pasteurella (P.) multocida is usually regarded as a coloniser of the upper respiratory system and only occasionally as a cause of mastitis $[28,35]$. In addition to transmission from cow to cow, a distribution via blood and the lymph from the respiratory tract might also be a possible route to infect the mammary gland [28]. Furthermore, there is evidence in older literature of an association between suckling of infected calves and the development of clinical mastitis [36]. With regard to the present study, this way of transmission may be feasible in a foster cow system but requires further investigations.

\subsection{Classification in Categories of Udder Health}

According to previous studies, suckling has either a positive or no effect on udder health. Several authors observed a reduction in IMI and SCC in suckled cows, but they often examined cows which were suckled by only one calf, mainly after milking. Thus far, only several studies have focused on foster cows and several of these found a positive effect of suckling on udder health (e.g., $[13,19])$. In none of the known studies is a significant negative effect mentioned. However, certain studies are also relatively old or were conducted under completely different conditions, for example in the tropics or with other cattle breeds [13], thus making comparability difficult. Furthermore, in certain 
cases, publication bias cannot be excluded completely. The present study shows significant changes concerning the classification into the different mastitis categories between the two examinations. This includes a slight increase in the rate of foster cows considered as udder healthy between the two examinations (E1: $32.5 \%$, E2: $41 \%$ of 385 quarters). However, the interpretation should consider that a diagnosis was not possible when the sample was contaminated or the SCC was not measurable. Nevertheless, these results are similar to those of Hansmann et al. [37] who found an average of $45.4 \%$ of the cows in 21 German organic dairy herds with SCC $\leq 100,000$ cells $/ \mathrm{mL}$ milk. In the present study, the number of quarters with mastitis (E1: 10.9\%, E2: 8.3\% of 385 quarters) and non-specific mastitis (E1: $19.2 \%$, E2: $7.8 \%$ of 385 quarters) decreased, whereas the number of quarters with a latent infection increased (E1: 11.2\%, E2: 16.6\% of 385 quarters) during the suckling period. The former was mainly associated with a decline in the number of $\mathrm{NaS}$ and Corynebacterium spp., which is also reflected in the bacteriological cure rate. Previous studies support these findings, although comparability is limited due to the different study designs as mentioned earlier. Already in 1980, Alvarez et al. [38] observed a reduced incidence of subclinical mastitis in crossbred European/Zebu conga, which were suckled by their calves after milking. González- Sedano et al. [16] determined a 1.59 times higher risk for non-suckled cows to develop subclinical mastitis in comparison to restrictive suckled cows in dual-purpose cows in Mexico. The risk of developing clinical mastitis was considered to be 6.59 times higher. This former study attributed the improvement in udder health to the more complete emptying of the mammary gland by the calves, which leads to a reduction in substrate for bacterial growth. Another reason may be the presence of antimicrobial lysozymes in the saliva of the calves [16]. Conversely, the observed increase in the incidence of latent infections might confirm the concerns of Wagenaar and Langhout [4]. They feared an impairment of teat closure due to the frequent suckling of the calves. As a consequence, this could facilitate the entry of bacteria into the mammary gland. A possible transmission of pathogens between the udder of the foster cow and the suckling calf should be examined in this context. In 1942, Schalm [39] investigated the prevalence of Sc. agalactiae in the oral cavity of four calves after ingesting milk from infected cows. Cross-suckling of the teats was observed in the calves and in one animal the pathogen was subsequently isolated from the teats. In addition, calves often suckle on more than one cow, especially if their biological mother is not in the foster group [10]. This behaviour was also observable in the foster calves in the present study.

\subsection{Bacteriological and Cytological Cure Rate}

The bacteriological cure rate was high, with $69.3 \%$. NaS (29.8\%) and Corynebacterium spp. $(19 \%)$ contributed the most as they were the most prevalent detected pathogen species in both E1 and E2. However, an assessment is hampered by the lack of a control group as well as from the lack of previous studies. In addition, foster cows with clinical mastitis were removed from the group before the second sampling, which might have influenced the bacteriological cure rate.

The cytological cure rate in the present study was $28.1 \%$, which is poor. Conversely, the mean values of the SCS showed a significant decrease from E1 to E2 $(p<0.001)$. Previous studies present varying results concerning the SCC. In restricted suckling systems, where calves suckle on cows for a limited time after milking, an improvement in SCC was observed in several cases. This may be due to the reduction in the number of pathogens as a result of the more effective udder emptying by the calf (e.g., $[13,17])$. For instance, Boonbrahm et al. [17] compared the restricted suckling with the machine milking of Holstein Friesian crossbred cows in Thailand. The authors transformed the measured SCC into an SCS with a cut-off value of 100,000 cells $/ \mathrm{mL}$ and investigated a highly significant lower SCS $(p<0.001)$ in restrictive suckled cows. The study by Margerison et al. [13] focused on tropical cows in Colombia and determined a lower mean SCC $(p=0.05)$ in restrictive suckled cows compared to non-suckled cows. The mean SCC of cows multiply suckled by other cows' calves was even lower compared to cows suckled by their own calf 
(85,000 cells / $\mathrm{mL}$ and 95,000 cells / mL, respectively). Fröberg et al. [40] conducted a study with Holstein cows in Mexico and determined a tendency of better results in the California Mastitis Test (CMT, $p=0.08$ ) of restrictive suckled cows compared to non-suckled cows. Conversely, the overall incidence of mastitis was comparatively high in both groups and probably due to deficiencies in husbandry and milking hygiene. Other authors either detected no influence of suckling on the SCC [4] or a slight increase [41]. The latter may be a consequence of the combination of both milking and suckling, which places more stress on the teats.

Nevertheless, the comparability of the examples mentioned to the present study is limited, since not only cattle breed, farm management and climate zone differed, but also the SCC threshold values. Moreover, the calves in the present study had not only restricted but permanent access to the foster cows and could suckle them at any time for a period of approximately three months. In this context, recurrent contact with the oral cavity flora of different calves could contribute to an increase in SCC compared to machine milking. Due to a lack of studies focusing on foster cows, it has not yet clearly been proven whether an increased SCC is not even more common in such a rearing system. In beef cows, which have also permanent contact with their calves for a longer period of time, an elevated SCC could have been observed in several cases. For instance, Waller et al. [42] examined 109 beef cows within a month after calving and once at weaning. Although the results varied markedly between the herds, at both times, approximately $50 \%$ of the cows had an SCC $\geq 200,000 / \mathrm{mL}$, indicating subclinical mastitis. Furthermore, as is generally known, older cows tend to have IMI more frequently. This aspect should be considered since the majority of the foster cows in the present study were at least in their third lactation.

\subsection{Ratio of New Infections to Persistent Infections}

The number of infected quarters both at the beginning as at the end of the suckling period was almost equal (31.4\% and $31.7 \%$ of 385 quarters, respectively). In this timeframe, mainly new infections happened and amounted to $73 \%$ in relation to presumed persistent infections (18.9\%). These results are similar to the examinations of Nitz et al. [32] who could prove a high prevalence of new infections in the first days after calving. Additionally, it may be conceivable that certain presumed persistent infections were reinfections with the same pathogen. Using the random amplified polymorphism DNA-polymerase chain reaction, Wente et al. [43] were able to confirm that this is likely in cases of recurrent mastitis.

Certain aspects of the udder health situation in the present study are not particularly satisfactory, especially the percentage of udder healthy quarters, the increase in latent infections and the low cytological cure rate. Conversely, the assessment is difficult because there are only several studies on the udder health of foster cows. Thus, not all results can be attributed solely to calf sucking and further studies with a control group from the same herd considering farm specific aspects are needed. Moreover, udder health is still considered to be a major problem in organic dairy farming [37]. Certain risk factors for mastitis are associated with this type of husbandry, including the limited use of antibiotic remedies, the feeding strategies or organic bedding material. The latter may increase the risk of udder infections caused by environmental pathogens [44].

\subsection{Results of Udder Examination}

The second main aim of the present study was to determine whether suckling multiple calves was associated with a deterioration in udder constitution. Therefore, the examination of the udder was conducted both at the beginning and shortly before the end of the suckling period. Significant changes were observed in udder oedema, consistency of udder quarters, UCD, udder skin lesions and teat condition. Nevertheless, it could not be clearly demonstrated that these changes are exclusively due to the calf suckling and not part of physiological processes. As an example, the reduction in udder oedema and the increased number of udder quarters with a consistency considered, as normal may be attributable to the development of the mammary gland with the progress of lactation and the increase 
in swelling around the time of calving. Regarding the teats, in other studies, a significant correlation between the number and period of lactation and different measurements such as teat height above the ground, teat length and teat diameter could be shown. For instance, Ceyhan et al. [45] found a decreased clearance of front and rear teats from the ground in cows in their second lactation compared to first lactating cows. In contrast, teat diameter and teat length increased. Akdag et al. [46] made similar observations on Jersey cows. Conversely, the available literature on the effects of suckling on teat condition is scarce. In 1990, Hamann and Stanitzke [47] measured changes of teat length, teat diameter and teat end thickness of seven early lactating heifers before and immediately after calf suckling, hand and machine milking. The different milking methods were not associated with changes in teat length exceeding $\pm 1 \mathrm{~mm}$. Changes in teat end diameter were also rather small for calf suckling and hand milking $(-0.4$ to $+0.3 \mathrm{~mm})$ in contrast to machine milking $(+2-3.5 \mathrm{~mm})$. After a few weeks of machine milking, this increase was less pronounced, as the tissue may have adapted to the stress. Teat end thickness decreased by $9.1 \%$ after calf suckling compared to an increase of up to $26.9 \%$ after machine milking. The authors attributed these changes to the fact that calf suckling removes blood and tissue fluids from the teat end compared to machine milking. These results contrast with those in the present study as the teat length and diameter in the latter significantly increased from E1 to E2. Nevertheless, the present study was conducted without a machine milked control group which makes interpretation of the measurements difficult.

Fröberg et al. [40] examined the effects of twice daily suckling after milking (30 min each for a total of eight weeks) on the udder health of Holstein cows in Mexico. They found the calves spending a significantly longer time suckling on the front teats than on the rear teats, particularly in the first weeks $(p<0.01)$. This observation was also made in other studies and may be due to the fact that rear quarters are harder to reach for younger calves and the often lower milk yield of the front quarters is initially sufficient for them [40]. The uneven suckling of calves should be kept in mind as a potential factor influencing udder health in a foster cow system and needs further investigations. Furthermore, the number of calves assigned to the cow as well as the duration of the suckling period could make a difference on how much stress is put on the mammary gland.

Udder cleft dermatitis describes an ulcerative inflammation of the mammary skin, which is usually located between the front quarters or at the transition of the front quarters and the abdominal wall [48]. Thus far, there have been no known studies suggesting a link between calf suckling and the development of UCD.

As early as 1974, Walsh [19] reported an increase in lesions on the teats of the foster cows possibly caused by the calves' teeth. According to Thomas et al. [22], these lesions have no negative effect on milk production but might make machine milking temporarily more difficult. Nevertheless, the teats usually recovered rapidly after weaning of the calves. Conversely, small lesions are associated with a higher risk of subclinical mastitis, especially when they are close to the teat canal [49]. In contrast to the teat lesions, the cause of the increase in udder skin lesions may not only be attributed to the suckling of the calves but to the bedding material made of straw. This aspect also requires further investigation.

\section{Conclusions}

Based on the present study, initial impressions of multiple suckling on the udder health of foster cows can be established. A foster period over several months does not seem to be associated with a significant deterioration in udder health but may contribute to a decrease in inflammation of the mammary gland. Further investigations with a higher number of study animals and a control group are required.

Author Contributions: Conceptualization, V.K.; methodology, V.K.; software, V.K.; validation, V.K. and S.L.; formal analysis, V.K.; investigation, K.K.; resources, K.K., N.W., Y.Z., and A.L.; data curation, V.K.; writing-original draft preparation, K.K.; writing—review and editing, V.K., S.L., N.W., and A.L.; visualization, K.K.; supervision, V.K.; project administration, V.K. All authors have read and agreed to the published version of the manuscript. 
Funding: This research was funded by the Steinbeis Research Center for Dairy Science (Kirchlengern, Germany), grant number 20-3.

Institutional Review Board Statement: In the present study, all applicable guidelines for the care and use of animals were considered. Approval was granted by the animal welfare committee of the university (University of Veterinary Medicine Hannover, Foundation; file reference: TVO-2020-V-70) on 13th July 2020. According to the local government, an application for animal testing was not necessary. The International Guiding Principles for Biomedical Research Involving Animals (1985) were followed.

Informed Consent Statement: Not applicable.

Data Availability Statement: All existing data are listed in the manuscript.

Acknowledgments: The authors would like to thank the farmers and personnel from the organic dairy farm for providing their foster cows and calves as well as their support, the personnel of the microbiology work group and all persons involved. A special thanks goes to Frances Sherwood-Brock for proofreading the English manuscript.

Conflicts of Interest: The authors declare no conflict of interest.

\section{References}

1. Newberry, R.C.; Swanson, J.C. Implications of breaking mother-young social bonds. Appl. Anim. Behav. Sci. 2008, 110, 3-23. [CrossRef]

2. Stěhulová, I.; Lidfors, L.; Špinka, M. Response of dairy cows and calves to early separation: Effect of calf age and visual and auditory contact after separation. Appl. Anim. Behav. Sci. 2008, 110, 144-165. [CrossRef]

3. Kälber, T.; Barth, K. Practical implications of suckling systems for dairy calves in organic production systems-a review. Landbauforschung 2014, 64, 45-58. [CrossRef]

4. Wagenaar, J.P.T.M.; Langhout, J. Practical implications of increasing 'natural living' through suckling systems in organic dairy calf rearing. NJAS Wagen. J. Life Sci. 2007, 54, 375-386. [CrossRef]

5. Busch, G.; Weary, D.M.; Spiller, A.; von Keyserlingk, M.A.G. American and German attitudes towards cow-calf separation on dairy farms. PLoS ONE 2017, 12, e0174013. [CrossRef]

6. Beaver, A.; Meagher, R.K.; von Keyserlingk, M.A.G.; Weary, D.M. Invited review: A systematic review of the effects of early separation on dairy cow and calf health. J Dairy Sci 2019, 102, 5784-5810. [CrossRef]

7. Johnsen, J.F.; Zipp, K.; Kälber, T.; de Passillé, A.M.; Knierim, U.; Barth, K.; Mejdell, C.M. Is rearing calves with the dam a feasible option for dairy farms?-Current and future research. Appl. Anim. Behav. Sci. 2015, 181, 1-11. [CrossRef]

8. Loberg, J.; Lidfors, L. Effect of stage of lactation and breed on dairy cows' acceptance of foster calves. Appl. Anim. Behav. Sci. 2001, 74, 97-108. [CrossRef]

9. Kent, J. The cow-calf relationship: From maternal responsiveness to the maternal bond and the possibilities for fostering. J. Dairy Res. 2020, 87, 101-107. [CrossRef]

10. Špinka, M.; Illmann, G. Suckling behaviour of young dairy calves with their own and alien mothers. Appl. Anim. Behav. Sci. 1992, 33, 165-173. [CrossRef]

11. Everitt, G.C.; Philips, D.S.M. Calf rearing by multiple suckling and the effects of lactation performance of the cow. NZ Soc. Anim. Prod. Proc. 1971, 31, 22-40.

12. Brouĉek, J.; Mihina, Š.; Uhrinčat, M.; Tančin, V.; Harcek, L.; Hetényi, L. Effect of suckling several calves on milk yield and reproduction of dairy cows. Zivocisna Vyrob. 1995, 40, 59-64.

13. Margerison, J.K.; Preston, T.R.; Philips, C.J.C. Restricted suckling of tropical dairy cows by their own calf or other cow's calves. J. Anim. Sci. 2002, 80, 1663-1670. [CrossRef]

14. Rigby, C.; Ugarte, J.; Boucourt, R. Rearing dairy calves by restricted suckling. VII. Effect on mastitis development caused by Staphylococcus aureus. Cuba. J. Agric. Sci. 1976, 10, 35-40.

15. Krohn, C.C.; Jonasen, B.; Munksgaard, L. Cow-Calf Relations II. The Effect of 0 Versus 5 Days Suckling on Behaviour, Milk Production and Udder Health of Cows in Different Stabling; Report No. 678; National Institute of Animal Science: Foulum, Denmark, 1990.

16. González-Sedano, M.; Marin-Mejia, B.; Maranto, M.I.; Leme de Magalhães-Labarthe, A.C.; Alonso-Diaz, M.A. Effect of residual calf suckling on clinical and sub-clinical infections of mastitis in dual-purpose cows: Epidemiological measurements. Res. Vet. Sci. 2010, 89, 362-366. [CrossRef]

17. Boonbrahm, N.; Peters, K.J.; Intisang, W. The influence of calf rearing methods and milking methods on performance traits of crossbred dairy cattle in Thailand. 1. Milk yield and udder health. Arch. Anim. Breed 2004, 47, 405-414. [CrossRef]

18. Andrade, R.; Pulido, M.; Molano, D. Effect of restricted suckling on somatic cell counts in cross holstein cows. Rev. MVZ Córdoba 2010, 15, 2095-2101.

19. Walsh, J.P. Milk secretion in machine-milked and suckled cows. Isr. J. Agric Res. 1974, 13, 77-89. 
20. Krömker, V.; Zinke, C.; Paduch, J.H.; Klocke, D.; Reimann, A.; Eller, G. Evaluation of increased milking frequency as an additional treatment for cows with clinical mastitis. J. Dairy Res. 2010, 77, 90-94. [CrossRef]

21. Fulkerson, W.J.; Hooley, R.D.; Findlay, J.K. Improvement in milk production of first calf heifers by multiple suckling. Aust. J. Agric. Res. 1978, 29, 351-357. [CrossRef]

22. Thomas, G.W.; Spiker, S.A.; Mickan, F.J. Influence of suckling by Friesian cows on milk production and anoestrus (meat calf rearing). Aust. J. Exp. Agric. 1981, 21, 5-11. [CrossRef]

23. Kilgour, R. Some observations on the suckling activity of calves on nurse cows. Proc. N. Z. Soc. Anim. Prod. 1972, $32,132-136$.

24. Rasmussen, M.D.; Larsen, H.D. The Effect of Post Milking Teat Dip and Suckling on Teat Skin Condition, Bacterial Colonisation, and Udder Health. Acta. Vet. Scand. 1998, 39, 443-452. [CrossRef]

25. Grunert, E. Weiblicher Geschlechtsapparat und Euter. In Die Klinische Untersuchung des Rindes, 4th ed.; Gründer, G., Stöber, M., Eds.; Enke-Verlag: Stuttgart, Germany, 2012; pp. 472-548.

26. Haverkamp, H.; Paduch, J.-H.; Klocke, D.; Hoedemaker, M.; Krömker, V. Prevalence of teat end hyperkeratosis in lactating dairy cattle and their association with animal variables. Int. J. Environ. Agric Res. 2017, 3. [CrossRef]

27. Mein, G.A.; Neijenhuis, F.; Morgan, W.F.; Reinemann, D.J.; Hillerton, J.E.; Baines, J.R.; Ohnstad, L.; Rasmussen, M.D.; Timms, L.; Britt, J.S.; et al. Evaluation of bovine teat condition in commercial dairy herds: 1 Non-infectious factors. National Mastitis Council Inc. In Proceedings of the 2nd International Symposium on Mastitis and Milk Quality, Vancouver, BC, Canada, 13-15 September 2001; National Mastitis Council Inc.: Madison, WI, USA, 2001; pp. 344-351.

28. German Veterinary Medical Association. Leitlinien zur Labordiagnostik der Mastitis_Probenahme und Mikrobiologische Untersuchung, 3rd ed.; German Veterinary Medical Association: Gießen, Germany, 2018.

29. Theel, E.S.; Schmitt, B.H.; Hall, L.; Cunningham, S.A.; Walchak, R.C.; Patel, R.; Wengenack, N.L. Formic Acid-Based Direct, On-Plate Testing of Yeast and Corynebacterium Species by Bruker Biotyper Matrix-Assisted Laser Desorption Ionization-Time of Flight Mass Spectrometry. J. Clin. Microbiol. 2012, 50, 3093-3095. [CrossRef]

30. German Veterinary Medical Association. Leitlinien zur Bekämpfung der Mastitis als Bestandsproblem, 5th ed.; German Veterinary Medical Association: Gießen, Germany, 2012.

31. Kiesner, K.; Wente, N.; Volling, O.; Krömker, V. Selection of cows for treatment at dry-off on organic farms. J. Dairy Res. 2016, 83, 468-475. [CrossRef]

32. Nitz, J.; Wente, N.; Zhang, Y.; Klocke, D.; tho Seeth, M.; Krömker, V. Dry Period or Early Lactation-Time of Onset and Associated Risk Factors for Intramammary Infections in Dairy Cows. Pathogens 2020, 10, 224. [CrossRef]

33. Nitz, J.; Krömker, V.; Klocke, D.; Wente, N.; Zhang, Y.; tho Seeth, M. Intramammary Infections in Heifers-Time of Onset and Associated Risk Factors. Animals 2020, 10, 1053. [CrossRef]

34. Benites, N.R.; Melville, P.A.; Costa, E.O. Evaluation of the Microbiological Status of Milk and Various Structures in Mammary Glands from Naturally Infected Dairy Cows. Trop. Anim. Health Prod. 2003, 35, 301-307. [CrossRef]

35. Milanov, D.; Aleksić, N.; Todorović, D.; Bugarski, D. Pasteurella multocida mastitis in cow: Case report. Vet. Glas. 2017, 71, 117-122. [CrossRef]

36. Barnum, D.A. A herd outbreak of mastitis caused by Pasteurella Multocida. Can. J. Comp. Med. 1954, 18, 113-119.

37. Hansmann, V.K.; Volling, O.; Krömker, V. Udder health in organic dairy herds in Northern Germany. Milchwiss. Milk Sci. Int. 2019, 72, 6-23. [CrossRef]

38. Alvarez, F.J.; Saucedo, G.; Arriaga, A.; Preston, T.R. Effect on milk production and calf performance of milking crossbred European/Zebu cattle in the absence or presence of the calf, and of rearing their calves artificially. Trop. Anim. Prod. 1980, 5, 25-27.

39. Schalm, O.W. Streptococcus agalactiae in the udders of heifers at parturition traced to sucking among calves. Cornell Vet. 1942, 32, 49-60.

40. Fröberg, S.; Gratte, E.; Svennersten-Sjaunja, K.; Olsson, I.; Berg, C.; Orihuela, A.; Galina, G.S.; García, B.; Lidfors, L. Effect of suckling ('restricted suckling') on dairy cows' udder health and milk let-down and their calves' weight gain, feed intake and behaviour. Appl. Anim. Behav. Sci. 2008, 113, 1-14. [CrossRef]

41. Barth, K. Effect of suckling on milk yield and milk composition of dairy cows in cow-calf contact systems. J. Dairy Res. 2020, 87, 133-137. [CrossRef]

42. Waller, K.P.; Persson, Y.; Nyman, A.-K.; Stengärde, L. Udder health in beef cows and its association with calf growth. Acta Vet. Scand 2014, 56, 1-8. [CrossRef]

43. Wente, N.; Grieger, A.S.; Klocke, D.; Paduch, J.-H.; Zhang, Y.; Leimbach, S.; tho Seeth, M.; Mansion-De Vries, E.M.; Mohr, E.; Kroemker, V. Recurrent mastitis- persistent or new infections? Vet. Microbiol. 2020, 244. [CrossRef]

44. Vaarst, M. Mastitis in Danish organic dairying. Proc. Br. Mastit. Conf. 2001,1-12.

45. Ceyhan, A.; Cinar, M.; Serbeser, U. Milk Yield, Somatic Cell Count, and Udder Measurements in Holstein Cows at Different Lactation Number and Month. Media Peternak. 2015, 38, 118-122. [CrossRef]

46. Akdag, F.; Ugurlu, M.; Gurler, H.; Teke, B.; Kocak, O. The relationships between udder traits and milk yield, milk composition, and subclinical mastitis in Jersey cows. Large Anim. Rev. 2017, 23, 203-209.

47. Hamann, J.; Stanitzke, U. Studies on pathogenesis of bovine mastitis by comparison of milking conditions as calf suckling, hand milking and machine milking. Milchwissenschaft 1990, 45, 632-637. 
48. Olde Riekerink, R.G.M.; van Amersfort, K.; Sampimon, O.C.; Hoojer, G.A.; Lam, T.J.G.M. Short communication: Prevalence, risk factors, and a field scoring system for udder cleft dermatitis in Dutch dairy herds. J. Dairy Sci. 2014, 97, 5007-5011. [CrossRef]

49. Agger, J.F.; Willeberg, P. Epidemiology of teat lesions in a dairy herd. II. Associations with subclinical mastitis. Nord. Vet.-Med. 1986, 38, 220-232. 